\title{
1. Intra-EU migration and social rights: an introduction
}

\section{Martin Seeleib-Kaiser and Frans Pennings}

Marshall (1950) conceptualizes citizenship as a status of membership in a community; social rights are defined as core for the ability of all citizens, irrespective of class, to more fully enjoy political and civil rights. According to Marshall, social rights encompass everything from the right to a modicum of economic welfare to the right to live the life of a civilized being according to the standards prevailing in the society. The evolution of social rights, and of the welfare state more generally, was closely linked to the establishment of the nation state. Moreover, the nation state was sovereign to limit the provision of social rights and benefits to its citizens. However, the process of European integration has gradually eroded the sovereignty of EU Member States to limit service provision and granting of benefits to their citizens and territory. Nevertheless, Member States remain the primary institutions responsible for determining the overall design of social policies in a multi-tiered polity guided by the principle of subsidiarity (Leibfried and Pierson 1995). Therefore, it is not surprising that the institutional design of social policy varies significantly within the European Union since some welfare states are built on the principle of universalism, others on promoting social stability, and others still on mitigating poverty. Moreover, concepts of social rights or social citizenship do not have a uniform meaning and applicability across the EU and the real worlds of EU citizens' social rights differ greatly among Member States (cf. Ferragina and SeeleibKaiser 2011; Ferragina et al. 2015).

EU citizenship is a recent concept introduced by the Treaty of Maastricht (1992). It is of particular importance as previously the rights ensured by the Treaties and the right to free movement had been largely limited to workers and self-employed persons. Since Maastricht, they can be enjoyed also by economically inactive persons. EU citizens have the right to reside on the territory of another Member State for a period longer than three months, if they are 'workers' or 'self-employed 
persons', or have sufficient resources for themselves and their family members not to become a burden on the social assistance system of the 'host' Member State and have comprehensive sickness insurance, or are students with comprehensive sickness insurance, or family members accompanying or joining an EU citizen, who fulfils the criteria. The social rights of 'workers' significantly differ from those of the other groups, as Member States are bound by the principle of nondiscrimination with regards to social rights from the day of arrival.

Social rights of EU citizens have been at the centre of political debate in a number of Member States, most prominently in the debate leading to the British referendum to leave the European Union. The dominant political discourse characterized EU citizens as taking more out of the British welfare state than contributing to it. But 'welfare tourism' and 'poverty migration' as concepts within populist political debates are not only prevalent in Britain, but are also on the rise in a number of other Member States. These debates have the potential to undermine one of the principles of European integration, namely the freedom of movement, and jeopardize the entire project of European integration. The key issue relating to social rights for EU citizens is that of solidarity within bounded worlds of justice or 'selective solidarity' (Koning 2013), and boils down to this simple question: Who is us? Although dominant discourses in Member States about EU citizenship and associated social rights are highly varied, ${ }^{1}$ support for freedom of movement and access to social rights by EU migrant citizens is rather weak in a number of Member States. According to the Eurobarometer Survey conducted in Spring 2016, only 50 per cent of the respondents in Italy and the United Kingdom were of the opinion that it is a 'good thing' for EU citizens to live there, while about 80 per cent of the respondents in Lithuania, Spain, Latvia, Finland, Ireland, Portugal, and Sweden were of the opinion that it is a 'good thing' for other EU citizens to live in their respective countries (EU Commission 2016). While some evidence points to a shared solidarity of nationals with EU citizens from other Member States (Gerhards and Lengfeld 2014), it remains an empirical question, whether solidarity can be organized beyond the nation state (Habermas 2004).

This book analyses to what extent 'EU migrant citizens' have access to certain social benefits and services two decades after the introduction of EU Citizenship. We define 'EU migrant citizens' as EU citizens that have migrated to another EU Member State, thereby excluding tourists, cross-border mobile workers or posted workers within the EU. Two criteria guided the selection of countries to be included in our analysis: (a) the nature of the welfare regimes, and (b) the degree of intra-EU migration. Based on these selection criteria we have included the 
following countries in our analysis: Denmark, Estonia, Germany, the Netherlands, Poland, Spain, Sweden, and the UK (see Table 1.1).

Table 1.1 Welfare state regimes and degree of intra-EU immigration

\begin{tabular}{lccc}
\hline Welfare State & \multicolumn{3}{c}{ Degree of Intra-EU Immigration } \\
\cline { 2 - 4 } Regime & Low & Medium & High \\
\hline Mediterranean & & & Spain \\
Residual/liberal & Estonia & & UK \\
Conservative & Poland & Netherlands & Germany \\
Social & & Denmark & Sweden \\
Democratic & & & \\
\hline
\end{tabular}

For much of the 1990s social rights of EU migrant citizens were de facto of minor importance, as mobility within the EU was relatively low. However, primarily as a result of countries in Central and Eastern Europe (CEE) joining the European Union in the 2000s and the end of the associated transition agreements limiting freedom of movement as well as due to the severe economic crisis in Southern European (SE) countries, the number of EU migrant citizens has significantly increased across many Member States in Western Europe (see Figure 1.1).

Aside from the commonality of an increase of citizens from new Member States, the composition of EU migrant populations remains distinct across countries. This reflects, among other things, geography, earlier patterns of migration, and cultural and linguistic ties. Citizens from neighbouring countries often constitute one of the biggest groups of EU migrant citizens. Among EU migrant citizens in Denmark we predominantly find Swedish and German citizens; in Germany, Austrian and Polish citizens; in the Netherlands, German and Belgian citizens; in Sweden, Danish and Finnish citizens; and in the UK, Irish citizens. Spain stands out from the other countries; here linguistic rather than geographical dimensions appear the more important factor. The importance of previous migration histories and established networks is also evident. For instance, many of the EU migrant citizens in Germany from Southern European Member States will have migrated as 'guest workers' or are the descendants of these earlier labour migrants, who have not taken up German citizenship.

EU migrant citizens are generally younger than the national populations. The majority of EU migrant citizens are in their prime working age (25-54). There are nevertheless variations across countries in the age 

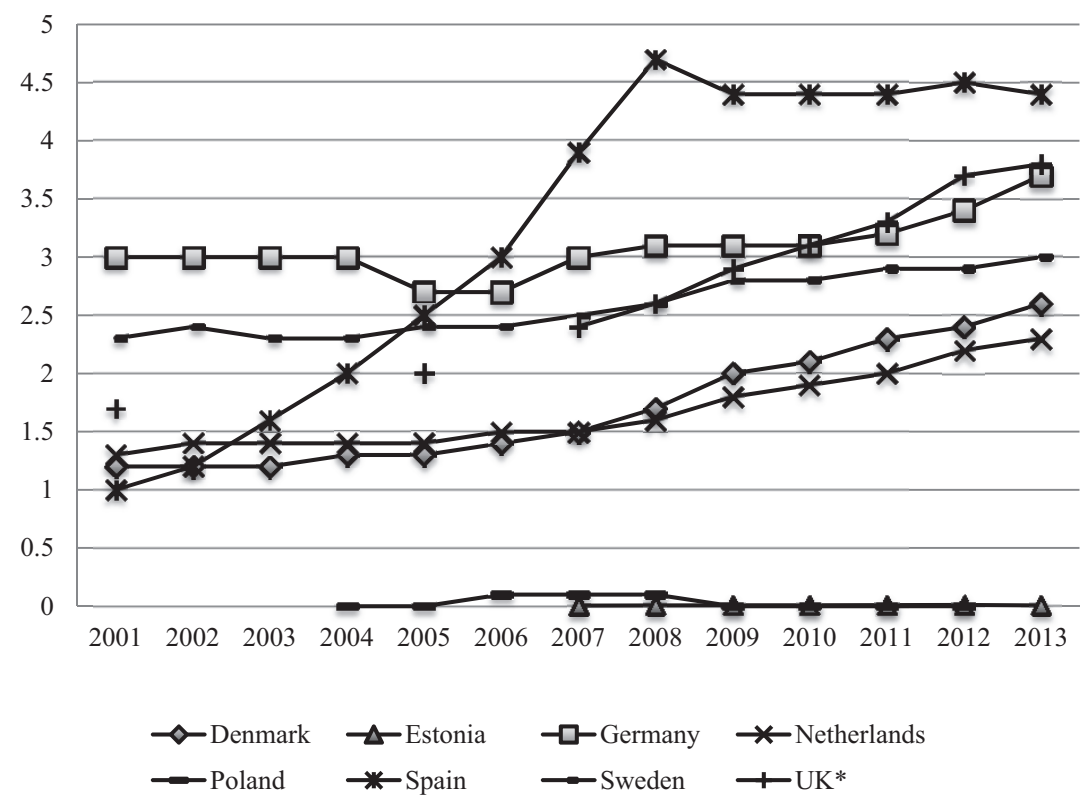

Note: * The dotted line indicates missing data for the UK.

Source: Eurostat, Population on 1 January by five-year age group, sex and citizenship.

\section{Figure 1.1 EU migrant citizens as percentage of total population (2001-2013)}

distribution of EU migrant populations. Denmark has a comparatively high proportion of EU citizens in the age group 15-24, potentially reflecting the large number of young people coming to study in Denmark. The United Kingdom, meanwhile, has the largest share of EU migrant citizens of prime working age (25-54), which partially reflects the more recent immigration from CEE and the very low share of established EU migrant communities, other than from Ireland, prior to enlargement. Germany in turn has comparatively lower shares of prime working age migrant citizens as a proportion among EU migrant citizens, most likely a result of earlier immigration of EU migrant citizens, who came to Germany in the 1960s and 1970s as 'guest workers'. Similarly, the EU migrant population in Sweden is comparatively old (but still younger than the national population), which reflects the presence of a long-established Finnish population. Spain's comparatively large share of older EU migrant citizens in contrast reflects EU citizens (in particular, British and German citizens) coming to retire in the country. However, in 
all countries analysed, the share of the EU migrant citizen population in their prime working age is larger than among the overall resident population. Data on EU migrant citizens making use of their social rights are quite limited. Statistics relating to benefit receipt among EU migrant citizens are often not available or quite difficult to access, despite political debates about so-called 'benefit tourism' in a number of countries. The data available for the key destination countries of Germany, Sweden, and the UK, for instance, seem to suggest that EU migrant citizens of working age are less likely to receive benefits than the overall resident population (Seeleib-Kaiser 2015).

In our analysis we will focus on access to social assistance, health care, housing and education. These social rights are of particular relevance to economically non-active persons, since they are available also for persons without a work record in the destination country. Moreover, they are important basic rights, essential for a decent life (providing a subsistence income, protection of health and accommodation and creating a basis for the future). This focus excludes traditional statutory social security rights, including old-age, unemployment, sickness, disability and family benefits, since these are subject to the coordination of social security (Regulation 883/2004) (see Pennings 2015). Consequently, we will not study the social rights of pensioners or the right of unemployed workers to export their unemployment insurance entitlements from their country of origin to another Member State. Access to social assistance, health care, housing and education relates to an essential dimension of EU citizenship, as it relates the rights of all persons, including the non-economically active, to free movement. Moreover, it is access to these social rights by EU migrant citizens that is often perceived by 'national citizens' as a threat to the national welfare state.

Our book is structured in the following way: The first part of our book discusses the international and supranational framework of social rights. Chapter 2 approaches the issue of social rights in Europe from a normative perspective. Andrzej Marian Świątkowski and Marcin Wujczyk investigate whether standards can be derived from the Social Charter of the Council of Europe that may be of use in establishing a minimum floor of social rights for citizens. Chapter 3 by Catherine Jacqueson focuses on the strength of EU social rights of inactive Union citizens over time. It is argued that these rights have been mainly the creation of the European Court of Justice, which has been the motor in promoting equal treatment of Union citizens. While the EU Court initially paved the way for more equality among migrant nationals, the EU legislator introduced several restrictions to this in the Citizenship 
Directive, whereupon the Court started to embark on a restrictive path towards social rights for non-economically active persons.

Part II draws on insights from law and public policy and analyses EU citizenship and social rights from a comparative perspective. In Chapter 4 Cecilia Bruzelius, Catherine Jacqueson and Martin Seeleib-Kaiser analyse the development of EU social policy, highlighting the limited role of the EU and the dominant role of Member States in determining social rights and outcomes. The chapter provides the context for the subsequent analyses. In Chapter 5 Frans Pennings discusses the legal impediments for EU migrant citizens in accessing social rights in the destination Member State. The chapter intends to take account of both the applicable EU law as well as the reality of limited access and aims to find an explanation for the frictions in destination countries of EU migrant citizens. In Chapter 6 Sara Stendahl and Otto Swedrup analyse the possibilities and impediments for citizens seeking to enforce their social rights. This chapter has three theoretical focal points: social rights, redress mechanisms and citizenship. It investigates the character of the redress mechanisms developed in the eight countries to secure the enforcement of the selected social rights. The chapter concludes with a discussion on social human rights as a legal strategy to enhance EU citizenship.

Part III contains some case studies. In Chapter 7 Katarina HylténCavallius provides a case study regarding the need of residence registration in order to access social rights in Sweden, highlighting that formal public law structures in the destination country can make it difficult for an EU migrant citizen to access both benefits and services on equal terms with resident nationals. Nadine Absenger and Florian Blank argue in Chapter 8 that the European approach to social rights and labour market policies can be described as a contradictory project. This is illustrated by an analysis of the German case. In Chapter 9 Philip Martin, Lisa Scullion and Philip Brown analyse the situation of Roma, a group of EU citizens that is often discriminated against and at the core of political debates on EU citizenship. In Chapter 10 Pauline Phoa follows a 'Law and Literature' approach towards EU citizens' access to social benefits. She demonstrates that law is not just a set of rules or institutions, but a dialogical and literary activity, which can be analysed and criticized as such. This approach is applied with regard to landmark judgments on EU citizenship such as the Grzelczyk and the Dano cases. The author argues how a 'Law and Literature' approach to EU citizenship contributes to understanding and critically assessing the way in which legal narratives shape EU citizenship rights. Chapter 11, entitled The construction of social rights by Hartley Dean, provides an analysis of the social 
construction of social citizenship in eight European Union countries, considering both the historical evolution of social rights and the prevailing discourse of key policy actors. Social policy discourse across Europe is not cogently informed by any shared understanding of social citizenship. The chapter concludes with a discussion of the idea of a European Citizen's Income.

In Chapter 12 Martin Seeleib-Kaiser and Frans Pennings summarize the various dimensions and highlight that the meaning of social rights as part of EU citizenship has been and continues to be varied and contested.

\section{NOTE}

1. For a more elaborate discussion see Martin Seeleib-Kaiser (2015).

\section{REFERENCES}

EU Commission (2016), Standard Eurobarometer 85, Brussels: European Commission.

Ferragina, Emanuele and Martin Seeleib-Kaiser (2011), 'Thematic Review: Welfare Regime Debate: Past, Present, Futures?', Policy and Politics 39(4): 583-611.

Ferragina, Emanuele, Martin Seeleib-Kaiser and Thees Spreckelsen (2015), 'The Four Worlds of "Welfare Reality": Social Risks and Outcomes in Europe', Social Policy and Society 14(2): 287-307.

Gerhards, Jürgen and Holger Lengfeld (2014), Wir, ein europäisches Volk? Sozialintegration Europas und die Idee der Gleichheit aller europäischen Bürger, Wiesbaden: VS/Springer.

Habermas, Jürgen (2004), 'Solidarität jenseits des Nationalstaates', in Jens Beckert et al. (eds), Transnationale Solidarität, Frankfurt/Main: Campus, 225-235.

Koning, Edward Anthony (2013), Selective Solidarity: The politics of immigrants' social rights in Western welfare states, $\mathrm{PhD}$ Thesis, Kingston, Ontario: Queen's University.

Leibfried, Stephan and Paul Pierson (1995), European Social Policy, Washington, DC: Brookings.

Marshall, T.H. (1950), 'Citizenship and social class', in T.H. Marshall (ed.), Citizenship and Social Class: And Other Essays, London: Pluto, 3-51.

Pennings, Frans (2015), European Social Security Law, 6th edition, Antwerp: Intersentia.

Seeleib-Kaiser, Martin (2015), Social Rights of EU Migrant Citizens, bEUcitizen deliverable 6.1, bEUcitizenproject. 
Martin Seeleib-Kaiser and Frans Pennings - 9781788112710 Downloaded from PubFactory at 04/26/2023 11:09:53AM via free access 